\title{
Zooceuticals and Cosmetic Ingredients Derived from Animals
}

\author{
Luigi Cristiano $^{1,2, *(\mathbb{D})}$ and Manuela Guagni ${ }^{2}$ \\ 1 Research and Development Division, Prestige, 52024 Loro Ciuffenna, Italy \\ 2 New Line Academy, 50131 Firenze, Italy; manuela.guagni@mpspec.it \\ * Correspondence: prestige.infomed@gmail.com
}

Citation: Cristiano, L.; Guagni, M. Zooceuticals and Cosmetic

Ingredients Derived from Animals.

Cosmetics 2022, 9, 13.

https://doi.org/10.3390/

cosmetics 9010013

Academic Editor: Piera Di Martino

Received: 16 December 2021

Accepted: 18 January 2022

Published: 19 January 2022

Publisher's Note: MDPI stays neutral with regard to jurisdictional claims in published maps and institutional affiliations.

Copyright: (C) 2022 by the authors. Licensee MDPI, Basel, Switzerland. This article is an open access article distributed under the terms and conditions of the Creative Commons Attribution (CC BY) license (https:// creativecommons.org/licenses/by/ $4.0 /)$.

\begin{abstract}
Many substances derived from animals are used as ingredients in the cosmetic industry and constitute a particular type of product: zooceuticals. The main ingredients used can come from insects, such as snail slime; land animals, such as lanolin; and marine animals, such as marine collagen. Today, they are used less than in the past for hygienic-sanitary, ethical, and ecological reasons. Moreover, some can give rise to irritative or allergic dermatitis. However, they still represent a fraction of the common ingredients in certain types of cosmetic products today.
\end{abstract}

Keywords: cosmetics; cosmeceutics; zooceuticals; cosmetology; cosmetological chemistry; cosmetic ingredients; animals; beauty

\section{Introduction}

Cosmetic products containing ingredients of animal origin or, more generally, of zoological origin, are called zooceuticals [1,2]. This term is rarely used, and biocosmetics, cosmeceuticals, or natural cosmetics are spoken of more frequently because they contain ingredients of natural origin [3]. However, zooceuticals concern all cosmetic products for human use. They are not synonymous with "cosmetics for animals", which are completely different products and are only for veterinary use or for the skin-care or hair-care of pets.

The chemicals used as cosmetic ingredients, as is known, can be grouped into three main groups of ingredients. The first group consists of the basic ingredients, which form the major quantity of the cosmetic product. The second group is formed by the functional substances that give the specificity of action to the cosmetic product, and finally, in the third group, there are additives, i.e., all substances added in low quantities to improve the characteristics of the product in terms of quality, safety, texture, appearance, and pleasantness. Animal-derived ingredients can be used both as basic ingredients and as functional substances or additives, depending on the characteristics of the chemical used. Animal-derived ingredients are frequently polyfunctional, such as snail slime, and can contain a variety of substances with various cosmetic actions and uses, even if the majority of these chemicals are used as functional substances with moisturizing, soothing, anti-aging, or, more broadly, conditioning effects for the skin, hair, and/or scalp.

Animal derivatives, used as ingredients in cosmetics, often do not require the sacrifice of the animal-consider, for example, snail slime-or they are replaced by substances derived from plants, by chemical synthesis, or by biotechnological applications, such as hyaluronic acid, produced in the laboratory from bacterial cultures. In other cases, however, they represent by-products of the animal industry, such as crests, horns, hooves, and skin, and therefore derive from animal sacrifice [4].

Today, animal-derived ingredients are less frequently used for various reasons [5]. They include the infectious risk of some derivatives, but also ethical issues (animal cruelty) and concerns regarding the protection of biodiversity and endangered species, such as whales and turtles $[6,7]$.

In particular, the ethical issues regarding ingredients of animal origin for cosmetics refer both to respect for animals (animals suffer similarly to humans) and to the defense of 
biodiversity in order to preserve animal species from extinction. This includes defending the entire ecosystem. Laws have been enacted to protect endangered species of animals, and hunting for wildlife is regulated in many countries. In addition, consumer awareness has grown in this regard, as has society in general and the attention of manufacturing companies themselves. Certifications, such as vegan and halal, have proliferated to ensure that the ingredients in cosmetic products were obtained without causing animal cruelty or harm to animals $[8,9]$. Ingredients obtained without causing suffering or harm to animals, such as snail slime and the majority of bee derivatives, do not raise any ethical concerns. The situation is different as regards ingredients of animal origin deriving from breeding and the meat and fish industries: in this case, they represent by-products, i.e., waste from the production of products intended for food consumption [10]. The use of these byproducts in the cosmetic industry is allowed if they comply with purity, safety, and hygiene requirements. However, as mentioned above, where possible, they have been replaced by similar vegetable substances or by synthetic derivatives. Moreover, today, many animal ingredients used in past centuries have fallen into disuse because they are not effective or are dangerous to health [11].

As is true for all other substances used as cosmetic ingredients, both vegetable and synthetic, ingredients of animal origin, including their derivatives, must comply with the quality, purity, and safety requirements for use as ingredients in the cosmetic industry. Furthermore, they must not be toxic, contain impurities, or pose a health risk to the consumer, including the risk of transmission of infectious agents. Toxicity due to dermal exposure, including irritation, sensitization, and phototoxicity, has been assessed in toxicological studies, and any adverse effects are reported in cosmetovigilance [12].

To facilitate the classification of cosmetic ingredients of animal origin, it is possible to group them into categories, as proposed by Proserpio and Passerini [13] and reported in Figure 1, i.e., ingredients derived from insects (group A), derived from land animals (group B), and derived from marine animals (group C).

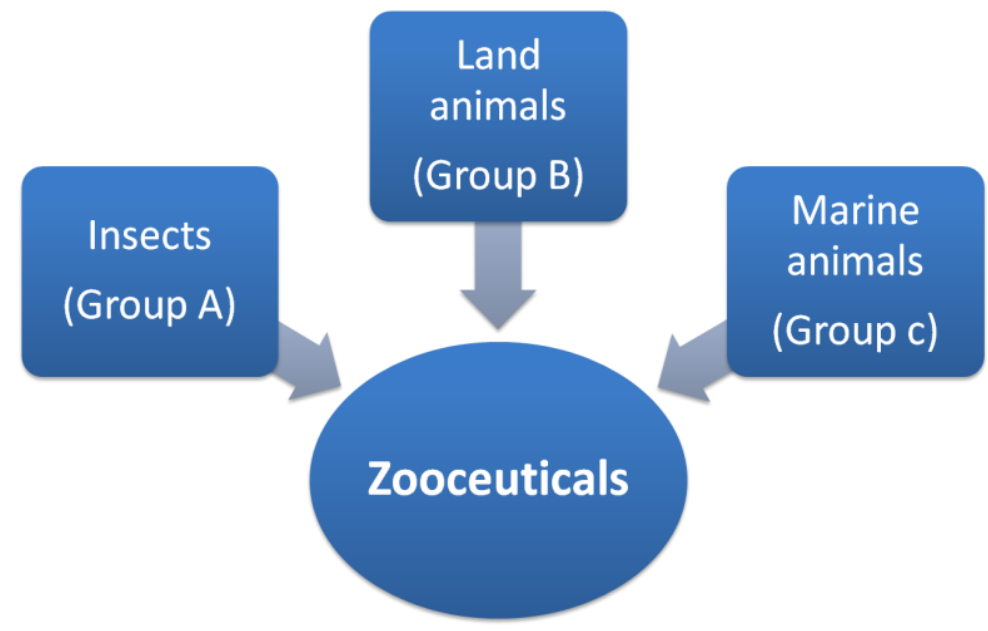

Figure 1. Grouping of ingredients of animal origin in zooceuticals.

\section{Ingredients Derived from Insects}

Substances derived from insects and used as ingredients in cosmetic products rarely result from animal sacrifice, and they are often obtained without causing animals to suffer. Thus, they are, in most cases, cruelty-free. They can be by-products of the bee, snail, and silk industries. The ingredients derived from these animals, generally grouped into the so-called Group A [13], are used especially as functional substances (for example, snail secretions, honey, and silk extract). They are less commonly used as basic ingredients (for example, fatty substances such as beeswax) or cosmetic additives (dyes such as carmin/CI 75470). 
Most of the cosmetic ingredients derived from insects come from bees and snails. Other less-used ingredients are obtained from cochineal, silkworms, and spiders. The most common cosmetic ingredients derived from insects are listed in Table 1.

Table 1. List of the most common cosmetic ingredients derived from insects (Group A) ${ }^{1}$.

\begin{tabular}{|c|c|c|c|c|}
\hline Animal Source & Ingredient & INCI Name & Functions & Category \\
\hline \multirow{8}{*}{ Bee } & Beeswax & Cera alba/Beeswax & $\begin{array}{l}\text { Emollient, emulsifying, } \\
\text { film forming, perfuming }\end{array}$ & - \\
\hline & Honey & Mel & $\begin{array}{c}\text { Humectant, skin } \\
\text { conditioning, flavoring }\end{array}$ & Honey cosmetics \\
\hline & Nectar & Nectar & $\begin{array}{l}\text { Humectant, skin } \\
\text { conditioning }\end{array}$ & - \\
\hline & Pollen & Pollen/pollen extract & $\begin{array}{l}\text { Emollient, skin } \\
\text { conditioning }\end{array}$ & Pollen cosmetics \\
\hline & Propolis & Propolis cera/extract & Skin conditioning & - \\
\hline & Royal jelly & Royal jelly/R.J. extract & Skin conditioning & - \\
\hline & Bee venom & $\begin{array}{c}\text { Bee venom/Bee venom } \\
\text { extract }\end{array}$ & $\begin{array}{l}\text { Astringent, skin } \\
\text { conditioning }\end{array}$ & - \\
\hline & Bee larva & $\begin{array}{l}\text { hydrolyzed bee larva } \\
\text { extract/queen bee larva }\end{array}$ & Skin conditioning & - \\
\hline \multirow[b]{2}{*}{ Beetle } & Beetle larva & Beetle larva extract & Skin conditioning & - \\
\hline & $\begin{array}{l}\text { Mealworm beetle (larva) } \\
\quad \text { (Tenebrio molitor) }\end{array}$ & Mealworm larva extract & $\begin{array}{l}\text { Humectant, skin } \\
\text { conditioning }\end{array}$ & - \\
\hline \multirow[b]{2}{*}{ Cochineal } & $\begin{array}{l}\text { Carmine cochineal } \\
\text { (Dactylopius coccus) }\end{array}$ & $\begin{array}{c}\text { CI } 75470 \text { (carmin/natural } \\
\text { red } 4)\end{array}$ & $\begin{array}{l}\text { Colorant, cosmetic } \\
\text { pigment }\end{array}$ & - \\
\hline & $\begin{array}{l}\text { Lacquer cochineal (Kerria } \\
\text { lacca-Laccifer lacca) }\end{array}$ & $\begin{array}{l}\text { Shellac/shellac } \\
\text { wax/shellac cera }\end{array}$ & $\begin{array}{l}\text { Emollient, film forming, } \\
\text { hair fixing, viscosity } \\
\text { controlling }\end{array}$ & - \\
\hline \multirow{4}{*}{ Silkworm } & Sericin & Sericin & $\begin{array}{l}\text { Smoothing, antistatic, } \\
\text { skin/hair conditioning }\end{array}$ & - \\
\hline & Silk & Silk/Silk extract/Serica & Skin/hair conditioning & - \\
\hline & Silk (hydrolyzed) & $\begin{array}{l}\text { Hydrolyzed silk/H. silk } \\
\text { protein }\end{array}$ & $\begin{array}{l}\text { Antistatic, humectant, } \\
\text { skin/hair conditioning }\end{array}$ & - \\
\hline & Silkworm extract & Bombyx mori extract & Skin conditioning & - \\
\hline \multirow{5}{*}{ Snail } & Allantoin (snail's slime) & Allantoin & $\begin{array}{l}\text { Soothing, skin/hair } \\
\text { conditioning }\end{array}$ & Snail cosmetics \\
\hline & Egg & Snail Egg Extract & Skin conditioning & Snail cosmetics \\
\hline & Slime & $\begin{array}{c}\text { Snail Slime Extract/Snail } \\
\text { Secretion Filtrate/Snail } \\
\text { Mucus Filtrate }\end{array}$ & $\begin{array}{l}\text { Skin conditioning, } \\
\text { antioxidant, humectant }\end{array}$ & Snail cosmetics \\
\hline & Slime (Helix aspersa muller) & $\begin{array}{c}\text { Helix Aspersa } \\
\text { Extract/Elicina }{ }^{\circledR}\end{array}$ & $\begin{array}{c}\text { Skin conditioning, } \\
\text { antioxidant, humectant }\end{array}$ & Snail cosmetics \\
\hline & Snail (Pomacea canaliculata) & Snail Extract & $\begin{array}{c}\text { Skin conditioning, } \\
\text { antioxidant, humectant }\end{array}$ & Snail cosmetics \\
\hline \multirow{3}{*}{ Spider } & Peptides (spider web) & $\begin{array}{c}\text { Spider } \\
\text { polypeptide-1/SP-4 }\end{array}$ & Skin/hair conditioning & - \\
\hline & Spider web & Spider Web Extract & Skin/hair conditioning & - \\
\hline & Spider web (hydrolyzed) & Hydrolyzed spider web & Skin conditioning & - \\
\hline
\end{tabular}

Carmine (INCI: carmin), also known as natural red 4 or, more formally, CI 75470, is obtained from Carmine cochineal (Dactylopius coccus). It is used as a pigment [15] and it can be found in various cosmetic products with an aesthetic-decorative function, such as lipsticks, eyeshadow, blush, nail polish, foundation, and concealer. 
Shellac (INCI: Shellac/shellac wax/shellac cera) is the resinous secretion obtained from Lacquer cochineal (Kerria lacca) and it is used as an ingredient in various cosmetic products, such as shampoos, nail polish, hairsprays, mascara, and lipsticks [16].

Silk, sericin, and their derivatives are often used in hair products, such as shampoo and conditioner, while an innovative ingredient is represented by polypeptides, obtained from spider web silk and used in various types of cosmetic products for the skin and hair.

\subsection{Bee Derivatives}

We know that bees, with their precious work, are the basis of the balance of our ecosystem. Many plant species would become extinct if they were not present, having serious consequences for the ecosystem, the food chain, and humans. Bees provide valuable hive products, such as honey, pollen, royal jelly, beeswax, and propolis, which have always been used and appreciated by people, in terms of both nutrition and as cosmetic ingredients. Bee venom is also added as a cosmetic ingredient [17].

One of the most commonly used cosmetic ingredients is honey (INCI: Mel). Honey is a functional substance used as a moisturizer and emollient. It deeply nourishes the epidermis and is rich in enzymes that are able to help with natural skin exfoliation [18]. It is added in the formulation of many cosmetic products, such as for dry and mature skin, and is widely used in night creams. It is also used in shampoos for light hair because it highlights the natural reflections and leaves the hair protected and bright [19]. Nothing prevents the use of common foods such as honey to prepare multipurpose masks. A nourishing mask can be obtained by mixing two generous spoons of honey with a few drops of lemon and a spoonful of extra virgin olive oil. Once the mixture has been prepared, it should be applied to the previously cleansed face and can be kept in place for up to fifteen minutes. The mask can then be removed with warm water. A honey scrub, on the other hand, can be obtained by mixing three tablespoons of honey with two to three tablespoons of whole brown sugar. The mixture thus obtained can be massaged all over the body and left on for approximately ten minutes. It can later be removed with warm water.

Another bee product widely used as an ingredient in cosmetics is beeswax (INCI: Beeswax). It is used both as a functional substance and as a base ingredient (stabilizer for emulsions, surfactant, emulsifying) or additive (rheological additive, viscosity control, texturizer, perfuming). Used as a functional substance, it has film-forming and eutrophic properties and is suitable for all skin types. It is also useful when applied to pimples because it is highly antibacterial and healing [20]. It minimizes expressive wrinkles and counteracts skin atony. In addition to the numerous cosmetic products on the market, creams can be prepared using solid beeswax grains, dissolving them in a bain-marie and customizing the preparations with the addition of various other ingredients-for example, with lavender essential oil for the treatment of impure skin, with lemon essential oil to have a greater antibacterial and skin-purifying action, and with olive oil to prepare an excellent butter for the lips.

Propolis (INCI: Propolis extract) is rich in flavonoids and phenols and has a positive action on blood circulation and capillary fragility [21]. It is often present in hand creams and anti-wrinkle creams for its strong nourishing and repairing action [22]. It can also be used in cleansers for oily and acne-prone skin, thanks to its purifying action [21,23].

Pollen (INCI: Pollen) can be mixed into vegetable oils, such as sunflower oil or rice oil, to obtain pollen oil [24]. This preparation is rich in vitamins such as vitamin A, vitamin C, pantothenic acid, and flavonoids. It is highly recommended for tired and impoverished skin. This oleolite can also be used on cracked elbows and heels to repair cracks more quickly.

Royal jelly (INCI: Royal jelly) stimulates cell metabolism and, for this reason, it is often used as an ingredient in anti-aging cosmetic products [25]. It is also very useful for regulating the secretions of the sebaceous glands and therefore can also be used on oily-prone skin. It is often present in many cosmetics for the care of the eye and lip area.

Bee venom (INCI: Bee venom) is a substance extracted from bees. It is a complex mixture of various substances, including enzymes, lipids, peptides, and bioactive amines [26]. 
It is also known as apitoxin and is used in cosmetics as an astringent and for its antiinflammatory, anti-ageing [27], and anti-bacterial [28] properties. It represents a new entry into the cosmetic field, particularly for mature skin. It is often considered among the botoxlike substances and is able both to promote the production of collagen and elastin and to act on the cutaneous neurotransmission mechanisms with the relaxation of the mimic muscles [29]. The effect obtained, as with the other botox-like molecules, is a transitory lifting effect.

Propolis and beeswax are substances that cause frequent allergic reactions (allergic contact dermatitis) and are therefore considered allergens [30,31].

\subsection{Snail Derivatives}

Snail slime is a complex secretion produced by snails. It is generally obtained from a genus of snail called Helix aspersa muller in a cruelty-free way, without animal sacrifice.

Nowadays, the interest of the cosmetic industry in skin applications and the benefits of snail slime is very high. The first studies on garden snails (Helix aspersa muller) began in 1958 with Melnick's preliminary analysis [32] and continued with Williams's work on snail mucus [33]. Initially, snails were used only as a food source, but in some snail farms, during the harvesting process, which involved the cleaning and manual handling of the animals, the skin was observed to be soft after being in contact with the snail secretion. Moreover, small cuts healed quickly, without infection or scarring [34]. This evidence has prompted some researchers to better analyze snail mucus to understand this interesting property.

Snail secretion consists of a dilute network of polymers, usually containing more than $95 \%$ water [35]. It contains various substances, including allantoin, elastin, collagen, mucopolysaccharides, glycolic acid, and vitamins. Mucous secretion is industrially treated before being added to creams, cleansers, and serums.

Snail slime has numerous properties: soothing and moisturizing, nourishing the skin, exfoliating and purifying, anti-wrinkle, anti-stretch marks, and anti-blemishes on the skin [36].

\section{Ingredients Derived from Land Animals}

Substances derived from land animals and used as ingredients in cosmetic products often result from animal sacrifice and/or are by-products of the meat and livestock industries. While, in the past, these substances were widely used, today, their use has been reduced in favor of the use of plant analogs or synthetic substances. The exclusion of some natural ingredients, such as civet oil and ambergris, is due to the protection of endangered species, to ethical issues related to violence against animals, and to health and hygiene issues $[5-7,11]$.

The ingredients derived from land animals, generally grouped into the so-called Group B, are used both as basic ingredients (for example, fats and fatty substances such as lanolin) and especially as functional substances (for example, hyaluronic acid, collagen, elastin, and keratin) in very different cosmetic products and for the most diverse uses, from moisturizing products for dry skin to anti-aging products. They are used less frequently as cosmetic additives.

Most of the cosmetic ingredients derived from land animals come from the cattle industry, especially collagen, elastin, and keratin. This is followed by the sheep industry, particularly for the extraction of lanolin, and the poultry industry to obtain the animal source of hyaluronic acid. Fats, milk, and other less-used ingredients are obtained from ducks, camels, horses, donkeys, minks, ostriches, pigs, and reptiles. The most common cosmetic ingredients derived from land animals are listed in Table 2. 
Table 2. List of the most common cosmetic ingredients derived from land animals (Group B) ${ }^{1}$.

\begin{tabular}{|c|c|c|c|c|}
\hline Animal Source & Ingredient & INCI Name & Functions & Category \\
\hline Bear & Fat & Bear oil & Skin conditioning & - \\
\hline Beaver & Castoreum $^{2}$ & $\begin{array}{l}\text { Castoreum/castoreum } \\
\text { oil }\end{array}$ & Fragrance & - \\
\hline \multirow{20}{*}{ Bovine } & Allantoin (urine) & Allantoin & $\begin{array}{l}\text { Soothing, skin } \\
\text { conditioning, skin } \\
\text { protecting }\end{array}$ & - \\
\hline & Amniotic fluid & Amniotic fluid & $\begin{array}{l}\text { Moisturizing, skin } \\
\text { conditioning }\end{array}$ & - \\
\hline & Bovine amniotic fluid & Amniotic Fluid & $\begin{array}{l}\text { Moisturizing, skin } \\
\text { conditioning }\end{array}$ & - \\
\hline & Collagen (ligaments) & Collagen & $\begin{array}{l}\text { Moisturizing, skin/hair } \\
\text { conditioning }\end{array}$ & - \\
\hline & Collagen (hydrolyzed) & Hydrolyzed collagen & $\begin{array}{l}\text { Humectant, antistatic, } \\
\text { emollient, film forming, } \\
\text { skin/hair conditioning }\end{array}$ & - \\
\hline & Elastin (ligaments) & Elastin & Soothing, skin conditioning & - \\
\hline & Elastin (hydrolyzed) & $\begin{array}{l}\text { Hydrolyzed elastin/E. } \\
\text { amino acids }\end{array}$ & $\begin{array}{l}\text { Emollient, skin/hair } \\
\text { conditioning }\end{array}$ & - \\
\hline & Fat (buffalo) & Buffalo fat & $\begin{array}{l}\text { Emollient, skin } \\
\text { conditioning }\end{array}$ & - \\
\hline & Fat (tallow) & Sodium tallowate & $\begin{array}{l}\text { Emollient, skin } \\
\text { conditioning }\end{array}$ & - \\
\hline & Bile (bovine) & Gall & Skin conditioning & - \\
\hline & $\begin{array}{l}\text { Keratin (horns, hairs, } \\
\text { hooves) }\end{array}$ & Keratin & Skin/hair conditioning & - \\
\hline & Keratin (hydrolyzed) & $\begin{array}{l}\text { Hydrolyzed keratin/K. } \\
\text { amino acids }\end{array}$ & $\begin{array}{l}\text { Humectant, antistatic, film } \\
\text { forming, skin/hair } \\
\text { conditioning }\end{array}$ & - \\
\hline & Milk & Lac/Milk & Skin conditioning & Milk cosmetics \\
\hline & Milk (buffalo) & Whole dry buffalo milk & Skin conditioning & Milk cosmetics \\
\hline & Milk (casein) & Casein/Casein extract & $\begin{array}{l}\text { Antistatic, skin/hair } \\
\text { conditioning }\end{array}$ & Milk cosmetics \\
\hline & Milk (casein, hydrolyzed) & Hydrolyzed casein & $\begin{array}{l}\text { Antistatic, skin/hair } \\
\text { conditioning }\end{array}$ & Milk cosmetics \\
\hline & Milk (yak) & Yak milk & Skin conditioning & Milk cosmetics \\
\hline & Placenta [37] & $\begin{array}{c}\text { Placental } \\
\text { extract/Placental } \\
\text { protein }\end{array}$ & Skin conditioning & - \\
\hline & Placenta (Hydrolyzed) [37] & $\begin{array}{c}\text { Hydrolyzed Placental } \\
\text { Extract }\end{array}$ & Skin conditioning & - \\
\hline & $\begin{array}{c}\text { Sperm (bull: Aberdeen } \\
\text { Angus) }\end{array}$ & Aberdeen Angus bull & Skin conditioning & - \\
\hline Camel & Milk & $\begin{array}{c}\text { Camel milk/Camel } \\
\text { milk extract }\end{array}$ & Skin conditioning & Milk cosmetics \\
\hline
\end{tabular}


Table 2. Cont.

\begin{tabular}{|c|c|c|c|c|}
\hline Animal Source & Ingredient & INCI Name & Functions & Category \\
\hline \multirow{4}{*}{ Chicken } & Albumen & $\begin{array}{c}\text { Albumen/Albumen } \\
\text { extract }\end{array}$ & $\begin{array}{l}\text { Film forming, skin/hair } \\
\text { conditioning }\end{array}$ & - \\
\hline & Albumen (hydrolyzed) & Hydrolyzed Albumen & $\begin{array}{l}\text { Antistatic, viscosity } \\
\text { controlling, skin/hair } \\
\text { conditioning }\end{array}$ & - \\
\hline & Egg & Egg/Egg extract & Skin/hair conditioning & Egg cosmetics \\
\hline & Hyaluronic acid (ridges) & $\begin{array}{l}\text { Hydrolyzed chicken } \\
\text { cartilage extract }\end{array}$ & $\begin{array}{l}\text { Humectant, antistatic, } \\
\text { moisturizing, film forming, } \\
\text { skin conditioning }\end{array}$ & - \\
\hline \multirow{2}{*}{ Duck } & Embryo & Duck embryo extract & $\begin{array}{l}\text { Moisturizing, skin } \\
\text { conditioning }\end{array}$ & - \\
\hline & Fat & Duck fat & Skin conditioning & - \\
\hline Emu & Fat (oil) & Emu oil & $\begin{array}{l}\text { Emollient, skin } \\
\text { conditioning }\end{array}$ & - \\
\hline \multirow{4}{*}{ Equine } & Fat (donkey) [38] & Donkey Oil & $\begin{array}{l}\text { Emollient, skin } \\
\text { conditioning }\end{array}$ & Milk cosmetics \\
\hline & Fat (horse) [38] & $\begin{array}{c}\text { Horse fat/oil/H. tissue } \\
\text { extract }\end{array}$ & $\begin{array}{l}\text { Emollient, skin } \\
\text { conditioning }\end{array}$ & - \\
\hline & Milk (donkey) & $\begin{array}{c}\text { Equus asinus } \\
\text { lac/donkey milk }\end{array}$ & Skin conditioning & Milk cosmetics \\
\hline & Milk (horse) & Equae lac/Mare milk & Skin conditioning & Milk cosmetics \\
\hline Mink/Civet & Mustele Oil/Civet oil & Mink Oil/Civet oil & Skin/hair conditioning & - \\
\hline \multirow{2}{*}{ Ostrich } & Egg & Ostrich egg yolk extract & $\begin{array}{l}\text { Antimicrobial, emollient, } \\
\text { skin conditioning }\end{array}$ & Egg cosmetics \\
\hline & Fat (oil) & Ostrich oil & $\begin{array}{l}\text { Emollient, skin/hair } \\
\text { conditioning }\end{array}$ & - \\
\hline \multirow{5}{*}{ Ovine/caprine } & Fat (goat milk) & Caprae Butyrum & Skin conditioning & Milk cosmetics \\
\hline & Lanolin (fleece) & Lanolin & $\begin{array}{l}\text { Emollient, antistatic, } \\
\text { emulsifying, surfactant, } \\
\text { skin/hair conditioning }\end{array}$ & $\begin{array}{l}\text { Lanolin } \\
\text { cosmetics }\end{array}$ \\
\hline & Lanolin derivatives & $\begin{array}{c}\text { Lanolin *, PEG * } \\
\text { lanolin, }{ }^{*} \text { lanolin, etc. }\end{array}$ & $\begin{array}{l}\text { Emollient, antistatic, } \\
\text { emulsifying, surfactant, } \\
\text { viscosity controlling, } \\
\text { skin/hair conditioning }\end{array}$ & $\begin{array}{l}\text { Lanolin } \\
\text { cosmetics }\end{array}$ \\
\hline & Milk (sheep) & Sheep milk & Skin conditioning & Milk cosmetics \\
\hline & Milk (goat) & $\begin{array}{c}\text { Caprae lac/Caprae Lac } \\
\text { Extract }\end{array}$ & Skin conditioning & Milk cosmetics \\
\hline
\end{tabular}


Table 2. Cont.

\begin{tabular}{|c|c|c|c|c|}
\hline Animal Source & Ingredient & INCI Name & Functions & Category \\
\hline \multirow{4}{*}{ Reptiles } & Fat/oil (crocodile) & Crocodile oil & $\begin{array}{l}\text { Emollient, skin } \\
\text { conditioning }\end{array}$ & - \\
\hline & Fat/oil (snake) & Snake oil & $\begin{array}{l}\text { Emollient, skin } \\
\text { conditioning }\end{array}$ & - \\
\hline & $\begin{array}{c}\text { Fat/oil (snake: Agkistrodon } \\
\text { halys blomhoffi) }\end{array}$ & Mamushi oil & Skin conditioning & - \\
\hline & Viper venom $^{3}$ & $\begin{array}{l}\text { Viper venom/viper v. } \\
\text { extract/snake v. }\end{array}$ & Skin conditioning & - \\
\hline \multirow{4}{*}{ Swine } & Lard & Hydrogenated lard & $\begin{array}{l}\text { Emollient, skin } \\
\text { conditioning }\end{array}$ & - \\
\hline & Placenta (hydrolyzed) [37] & $\begin{array}{l}\text { Hydrolyzed Placental } \\
\text { Extract }\end{array}$ & Skin conditioning & - \\
\hline & Stearic acid & Stearic acid & $\begin{array}{l}\text { Emulsifying, surfactant, } \\
\text { viscosity controlling }\end{array}$ & - \\
\hline & Magnesium stearate ${ }^{4}$ & Magnesium stearate & $\begin{array}{l}\text { Anticaking, bulking, } \\
\text { cosmetic colorant, } \\
\text { moisturizing }\end{array}$ & - \\
\hline \multicolumn{5}{|c|}{$\begin{array}{l}{ }^{1} \text { Reworked by Regulation (EC) No } 1223 / 2009 \text { (annexes III, IV), Commission Decision (EU) 2019/701, CosIng } \\
\text { database, InciDecoder database, INCI Beauty database, Proserpio and Contini [14]; }{ }^{2} \text { Today, it is rarely used and } \\
\text { only in luxury perfumery. }{ }^{3} \text { It is not the snake's venom but a synthetic substance called Dipeptide Diaminobutyroyl } \\
\text { Benzylamide Diacetate, which mimics its effects (it is one of the botox-like substances and, in particular, of the } \\
\text { biomimetic peptides). }{ }^{4} \text { Depending on the source, it can be plant- or animal-derived [15]. }\end{array}$} \\
\hline
\end{tabular}

Lanolin, including its fractions (INCI: lanolin/lanolin cera/lanolin wax/lanolin oil), is a wax secreted by sheep's skin that is obtained from the processing of wool. This substance accumulates on the woolly fleece as a natural protective and emollient for the animal and is formed by a mixture of chemical compounds, including esters of fatty acids and cholesterol [15]. The main derivatives of lanolin used as cosmetic ingredients are: acetylated lanolin (INCI: acetylated lanolin/acetylated hydrogenated lanolin), hydrogenated lanolin (INCI: hydrogenated lanolin/PEG-20 hydrogenated lanolin/acetylated hydrogenated lanolin), hydroxylated lanolin (INCI: hydroxylated lanolin), lanolin alcohols (INCI: lanolin alcohol/acetylated lanolin alcohol/PPG-20 lanolin alcohol ether), and other derivates (INCI: Lanolin Acid/PEG-NN lanolin, where NN is a number). It is widely used in creams and lip products and is rarely used in hair-care products. Lanolin is also a substance that causes frequent allergic reactions (allergic contact dermatitis) and is therefore considered an allergen [31]

One of the most commonly used ingredients in anti-aging cosmetics as a functional substance is collagen (and its derivatives). Natural sources of collagen are some animal sources, such as farmed land animals (bovines, swine), and some marine animals (fishes) $[39,40]$. The main sources of collagen are shown in Figure 2.

Following the epidemic of bovine spongiform encephalopathy (BSE), especially for cattle (mad cow disease), but also after transmissible spongiform encephalopathy (TSE), and avian and swine influences, many producers have chosen to resort to plant or synthetic analogs of animal derivatives in order not to run into problems regarding the safety of raw materials to be used as ingredients in cosmetic products [41]. 


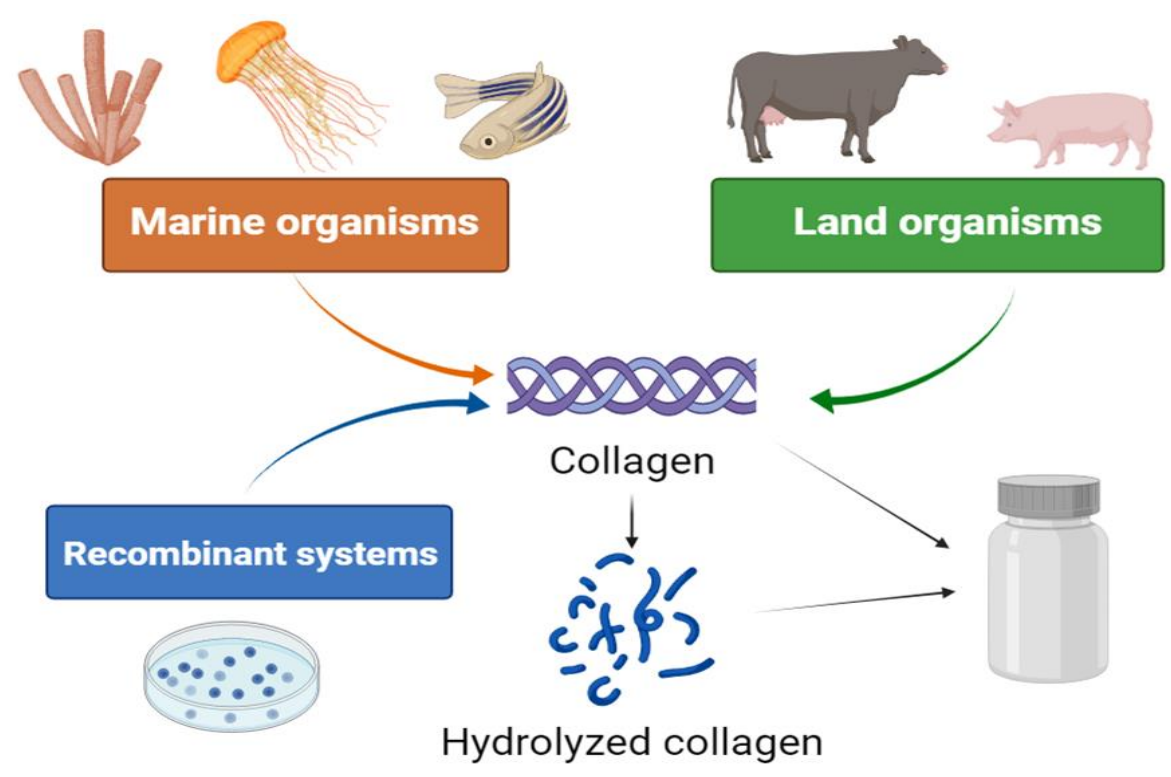

Figure 2. The main sources of collagen (created with BioRender.com (accessed on 10 December 2021); reworked by $[39,42])$.

As with collagen, elastin and its derivatives (INCI: elastin/hydrolyzed elastin) are popular in creams and anti-aging products. It is commonly extracted from the aorta or vertebrae of cattle [43].

Keratin and its derivatives (INCI: Keratin/hydrolyzed keratin) are widely used both in hair-care products (such as shampoo, conditioner, and hair masks) and nail-care products (strengthening nail polishes). Keratin is commonly extracted from the nails, feathers, horns, hair, claws, and hooves of various animals [44].

Hyaluronic acid is a very popular cosmetic ingredient, used as a functional substance in many skincare products, from skin hydration products to anti-aging products, in various cosmetic forms (creams, serums, shock vials). The animal source is the combs on the heads of roosters [45]. It is generally used as an ingredient in three different formulations, i.e., highmolecular-weight to create an invisible film with a skin barrier function (INCI: hyaluronic acid), medium-molecular-weight as a surface moisturizer, and low-molecular-weight as a skin moisturizer (INCI: hydrolyzed hyaluronic acid) [46-48].

Other ingredients derived from terrestrial animals are no longer used and have therefore fallen into disuse as they lack any real cosmetic effect or efficacy, linked to popular traditions and pseudo-sciences of past centuries (magical-alchemical traditions) or are even dangerous to human health. Some examples are goat feces, dog feces, rat feces, pig brain, ram's fat, chicken feather juice, turtle blood and oil, and toad blood [11]. Furthermore, some ingredients, such as milk (cow, horse, donkey), milk proteins, casein, milk derivatives, and the aforementioned lanolin, can cause dermatitis or allergies in sensitive and predisposed subjects [30].

\section{Ingredients Derived from Marine Animals}

Substances derived from marine animals and used as ingredients in cosmetic products often result from animal sacrifice and/or are by-products of the fishing industry. Some of these substances have been replaced with plant analogs or synthetic substances, as happened with ambergris.

Ingredients derived from marine animals, generally grouped into the so-called Group $\mathrm{C}$, are mainly used as functional substances (for example, marine collagen). In other cases, they are used as basic ingredients (for example, fish oil) or as cosmetic additives.

Most of the cosmetic ingredients of marine animals come from fish and some from crustaceans. Other ingredients, such as plankton, cuttlefish extract, and fish semen, are rarely used and are often found in high-end cosmetic products. 
The most common cosmetic ingredients derived from marine animals are listed in Table 3.

Table 3. List of the most common cosmetic ingredients derived from marine animals (Group C) ${ }^{1}$.

\begin{tabular}{|c|c|c|c|c|}
\hline Animal Source & Ingredient & INCI Name & Function & Category \\
\hline Cephalopods & Cuttlefish & Sepia extract & Skin conditioning & - \\
\hline Cetacean & Ambergris $^{2}$ & Musk ambrette & Fragrance & - \\
\hline \multirow{12}{*}{ Fish } & Cartilage & Fish cartilage extract & Skin conditioning & - \\
\hline & Collagen & Soluble Fish Collagen & Skin conditioning & - \\
\hline & Collagen (Hydrolyzed) & $\begin{array}{l}\text { Hydrolyzed Marine } \\
\text { Collagen }\end{array}$ & $\begin{array}{l}\text { Moisturizing, skin/hair } \\
\text { conditioning }\end{array}$ & - \\
\hline & DNA & DNA/Hydrolyzed DNA & Skin conditioning & - \\
\hline & Fat (codfish) & Cod Liver Oil & $\begin{array}{l}\text { Emollient, skin } \\
\text { conditioning }\end{array}$ & - \\
\hline & Fat (oil) & $\begin{array}{l}\text { Fish oil/hydrogenated fish } \\
\text { oil }\end{array}$ & $\begin{array}{l}\text { Emollient, skin } \\
\text { conditioning }\end{array}$ & - \\
\hline & Fat (shark) & Shark Liver Oil & $\begin{array}{l}\text { Emollient, skin } \\
\text { conditioning }\end{array}$ & - \\
\hline & Egg [38] & Salmon Egg & Skin/hair conditioning & Egg cosmetics \\
\hline & Fin extract (Isurus oxyrinchus) & Shark Fin Extract & $\begin{array}{l}\text { Emollient, humectant, skin } \\
\text { conditioning }\end{array}$ & - \\
\hline & Ovary & $\begin{array}{l}\text { Hydrolyzed salmon ovary } \\
\text { extract }\end{array}$ & $\begin{array}{l}\text { Emollient, skin } \\
\text { conditioning }\end{array}$ & - \\
\hline & Semen & Spermidine/sperm & Skin conditioning & - \\
\hline & Squalene (shark liver) ${ }^{3}$ & Squalene & $\begin{array}{l}\text { Emollient, antistatic, } \\
\text { skin/hair conditioning }\end{array}$ & - \\
\hline \multirow[t]{2}{*}{ Jellyfish } & $\begin{array}{c}\text { Collagen (Rhopilema asamushi, } \\
\text { Stomolophus meleagris, } \\
\text { Catostylus tagi, Rhizostoma } \\
\text { pulmo) [40] }\end{array}$ & Collagen & $\begin{array}{l}\text { Moisturizing, skin/hair } \\
\text { conditioning }\end{array}$ & - \\
\hline & Jellyfish & Jellyfish extract & $\begin{array}{l}\text { Humectant, skin } \\
\text { conditioning }\end{array}$ & - \\
\hline Plankton & Plankton & Plankton extract & Skin conditioning & $\begin{array}{l}\text { Plankton } \\
\text { cosmetics }\end{array}$ \\
\hline \multirow{3}{*}{ Porifer } & $\begin{array}{l}\text { Collagen (Geodia cydonium, } \\
\text { Speriditae, and Icinia fusca) [40] }\end{array}$ & Collagen & $\begin{array}{l}\text { Moisturizing, skin/hair } \\
\text { conditioning }\end{array}$ & - \\
\hline & Sponge & Sponge/Sponge extract & $\begin{array}{l}\text { Emollient, skin } \\
\text { conditioning }\end{array}$ & - \\
\hline & Sponge (hydrolyzed) & $\begin{array}{l}\text { Hydrolyzed Sponge/Hydr. } \\
\text { Sp. Extract }\end{array}$ & $\begin{array}{l}\text { Emollient, skin } \\
\text { conditioning }\end{array}$ & - \\
\hline Seal & Seal (fatty tissue) & Seal oil & Skin conditioning & - \\
\hline \multirow[b]{2}{*}{ Shellfish } & Chitin/chitosan [3] & Chitosan & Film forming, hair fixing & - \\
\hline & Chitosan (hydrolyzed) & Hydrolyzed chitosan & $\begin{array}{l}\text { Film forming, skin/hair } \\
\text { conditioning }\end{array}$ & - \\
\hline \multirow[t]{2}{*}{ Starfish } & Starfish powder [38] & $\begin{array}{c}\text { Starfish } \\
\text { extract/Hydrolyzed } \\
\text { starfish extract }\end{array}$ & Skin conditioning & - \\
\hline & $\begin{array}{l}{ }^{1} \text { Reworked by Reg } \\
\text { database, InciDecoc } \\
\text { from beached dead } \\
\text { substance (from veg }\end{array}$ & $\begin{array}{l}\text { on (EC) No } 1223 / 2009 \text { (annex } \\
\text { latabase, INCI Beauty databas } \\
\text { nals); today, obtained by chen } \\
\text { le oils). }\end{array}$ & $\begin{array}{l}\text { III, IV), Commission Decision (I } \\
\text { Proserpio and Contini [14]. }{ }^{2} \text { Ra } \\
\text { cal synthesis. }{ }^{3} \text { Replaced by squa }\end{array}$ & $\begin{array}{l}\text { J) } 2019 / 701, \text { CosIn } \\
\text { ly natural (obtaine } \\
\text { ane, a plant-derive }\end{array}$ \\
\hline
\end{tabular}


Ambergris is a strongly odorous substance produced by the intestines of sperm whales (Physeter macrocephalus). Its purpose is to defend the intestinal mucous membranes from the indigestible remains of the mollusks that the sperm whales eat, hardening around them and incorporating them [49].

The term ambergris is derived from the Old French "ambre gris," which means "gray amber," as opposed to "yellow amber," which refers to resinous amber [50]. It was used for making perfumes.

Chemically, ambergris consists mainly of a mixture of waxy, unsaturated, highmolecular-weight alcohols [50], and the main chemical constituent is ambrein. Other chemicals, such as epicoprosterol and coprosterol, have also been found, but ambrein is the substance that gives ambergris its typical odor [51]. The mechanism of formation of the typical ambergris odor is shown in Figure 3.

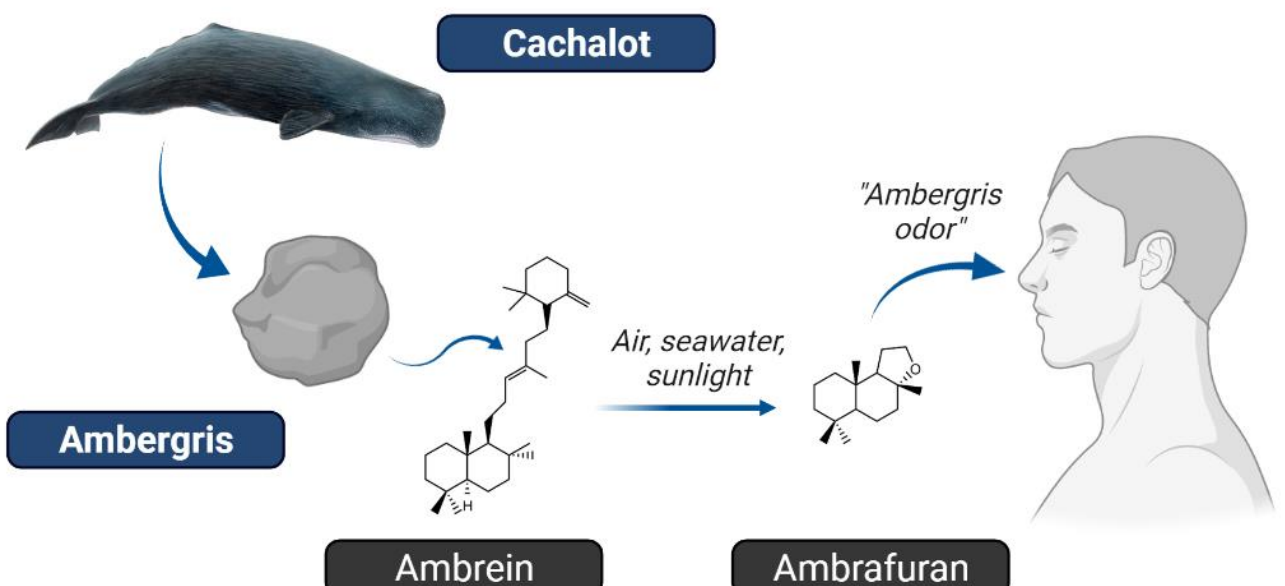

Figure 3. The mechanism of formation of the typical ambergris odor: due to the oxidative decomposition by seawater, air, and/or sunlight, ambrafuran is generated from the ambrein (created with BioRender.com (accessed on 10 December 2021); reworked by [52]).

Ambergris has now become extremely rare as the sperm whale is a protected species and cannot be hunted, so it has been replaced by synthetic substances. More rarely, it is possible to use the natural one if it is taken from beached dead animals, or sometimes it is recovered by fishermen when ambergris is regurgitated by the animal.

Chitosan and its derivatives (INCI: chitosan/Hydrolyzed chitosan) are linear polysaccharides composed of $\beta$ - $(1 \rightarrow 4)$-linked D-glucosamine and $\mathrm{N}$-acetyl-D-glucosamine that can be obtained from the chitin shells of shrimp and other crustaceans [15]. It is a by-product of the fishing industry. Chitosan and its derivatives are used as cosmetic ingredients in dental, skin, hair, and nail products [53].

\section{Conclusions}

In cosmetics, various substances of animal origin are used as ingredients. Products that contain animal derivates, in part (such as some types of face creams) or wholly (such as snail slime serums), are called zooceuticals.

The most common ingredients are beeswax, snail's slime and derivates, collagen, elastin, keratin and their respective hydrolyzed derivates, hyaluronic acid and derivates, lanolin and derivates, and chitosan. Other types of ingredients are used less frequently or in specific products, such as nail-care or hair-care, and many substances are now replaced by similar molecules extracted from plants, or of biotechnological or synthetic origin. This is due to hygienic-sanitary needs (preventing the spread of diseases, such as TSE/BSE), and ethical (cruelty-free) and ecological (safeguarding species in danger of extinction) concerns. Over the years, in fact, the sensitivity of consumers has greatly increased and the laws have rightly become more stringent in terms of the safety, ethics, and quality of cosmetic 
products (also thanks to the improvement of scientific knowledge and cosmetovigilance). Consequently, the attention of producers has also increased, and INCI formulas of cosmetic products today take into account all these factors, as well as compliance with other voluntary standards such as vegan, organic, kosher, and halal, which include or exclude one, more, or all ingredients of animal origin [54].

Author Contributions: Writing — original draft preparation, L.C.; writing-review and editing, L.C.; visualization, L.C., M.G.; cosmetic applications and bee derivatives, M.G. All authors have read and agreed to the published version of the manuscript.

Funding: This research received no external funding.

Institutional Review Board Statement: Not applicable.

Informed Consent Statement: Not applicable.

Data Availability Statement: The data presented in this study are openly available in CosIng database (https: / / ec.europa.eu/growth/sectors/cosmetics/cosmetic-ingredient-database_en (accessed on 6 December 2021)), InciDecoder database (https: / incidecoder.com/ (accessed on 9 December 2021), INCI Beauty database (https: / / incibeauty.com/en (accessed on 9 December 2021)) and in the references given in the tables and in the bibliography cited.

Conflicts of Interest: The authors declare no conflict of interest.

\section{References}

1. Adhikari, D.; Ray, S. Marine zooceuticals—Synergy of zoology \& pharmaceuticals. Pharmawave 2016, 9, 1-14.

2. Adhikari, D.; Mukherjee, S.; Ghosh, T. Zooceuticals-Promising Bio-molecules for Synthetic Simulation. Manan 2014, 1, 11-18.

3. Novak, A.C.; Sydney, E.B.; Soccol, C.R. Biocosmetics. In Biotransformation of Waste Biomass into High Value Biochemicals, 1st ed.; Brar, S., Dhillon, G., Soccol, C., Eds.; Springer: New York, NY, USA, 2014; pp. 389-411. [CrossRef]

4. EG Smith Collective. Chapter 4: Ingredients derived from animals. In Animal Ingredients A to Z, 3rd ed.; AK Press: Oakland, CA, USA, 2004; pp. 51-63.

5. Barros, C.; Barros, R.B.G. Natural and Organic Cosmetics: Definition and Concepts. Preprints 2020, 2020050374. [CrossRef]

6. Abedin, N.; Bashar, R.; Jimmy, A.N.; Khan, N.A. Unraveling Consumer Decisions towards Animal Ingredients in Personal-care Items: The Case of Dhaka City Dwellers. Am. J. Mark. Res. 2020, 6, 19-27.

7. Berger, C.N.; Le Donne, P.; Windemann, H. Use of substances of animal origin in pharmaceutics and compliance with the TSE-risk guideline-A market survey. Biologicals 2005, 33, 1-7. [CrossRef]

8. Chatterjee, S.; Sreen, N.; Rana, J.; Dhir, A.; Sadarangani, P.H. Impact of ethical certifications and product involvement on consumers decision to purchase ethical products at price premiums in an emerging market context. Int. Rev. Public Nonprofit Mark. 2021, 1-26. [CrossRef]

9. Hunter, M. The Emerging Halal Cosmetic and Personal Care market. Pers. Care Mag. 2012, 3, 37-41.

10. Barboza, S.I.S. Equilibrium of Marketing Systems Concept and Reflection on Animal-Based Industries. Food Ethics 2020, 5, 22. [CrossRef]

11. Betlloch, M.I.; Chiner, E.; Chiner-Betlloch, J.; Llorca-Ibi, F.X.; Martín-Pascual, L. The use of animals in medicine of Latin tradition: Study of the Tresor de Beutat, a medieval treatise devoted to female cosmetics. J. Ethnobiol. Trad. Med. 2014, 121, 752-760.

12. Burnett, C.L.; Heldreth, B.; Bergfeld, W.F.; Belsito, D.V.; Hill, R.A.; Klaassen, C.D.; Lieber, D.C.; Marks, J.G.; Shank, R.C.; Slaga, T.J.; et al. Safety assessment of amino acid alkyl amides as used in cosmetics. Int. J. Toxicol. 2017, 36, 17S-56S. [CrossRef]

13. Proserpio, G.; Passerini, E. Capitolo 6: La zoocosmesi. In Le Altre Cosmesi, 1st ed.; Tecniche Nuove: Milano, Italy, 2002; pp. 99-113.

14. Prosepio, G.; Contini, R. Gli Ingredienti Cosmetici. Guida alla Lettura dell'Etichetta dei Prodotti Cosmetici, 1st ed.; BCM: Milano, Italy, 1999.

15. Alamgir, A.N.M. Bioactive compounds and pharmaceutical excipients derived from animals, marine organisms, microorganisms, minerals, synthesized compounds, and pharmaceutical drugs. In Therapeutic Use of Medicinal Plants and Their Extracts: Volume 2, 1st ed.; Alamgir, A.N.M., Ed.; Springer: New York, NY, USA, 2018; pp. 311-406. [CrossRef]

16. Sabalingam, S.; Jayasuriya, W.B.N. Pharmaceutical excipients of marine and animal origin: A Review. Bio. Chem. Res. 2019, 6, 184-196.

17. Kurek-Górecka, A.; Górecki, M.; Rzepecka-Stojko, A.; Balwierz, R.; Stojko, J. Bee Products in Dermatology and Skin Care. Molecules 2020, 25, 556. [CrossRef] [PubMed]

18. Ball, D.W. The chemical composition of honey. J. Chem. Educ. 2007, 84, 1643. [CrossRef]

19. Burlando, B.; Cornara, L. Honey in dermatology and skin care: A review. J. Cosm. Dermatol. 2013, 12, 306-313. [CrossRef] [PubMed] 
20. Kedzia, B.; Hołderna-Kedzia, E. The Use of Beeswax in Medicine. Available online: https://pasieka24.pl/index.php/pl-pl/ pasieka-czasopismo-dla-pszczelarzy/108-pasieka-3-2014/1319-wykorzystanie-wosku-pszczelego-w-lecznictwie (accessed on 10 December 2021).

21. De Castro, S.L. Propolis: Biological and pharmacological activities. Therapeutic uses of this bee-product. ARBS Ann. Rev. Biomed. Sci. 2001, 3, 49-83. [CrossRef]

22. Sawicka, D.; Borawska, M.H. The use of propolis in skin diseases. Derm. Estet. 2013, 1, 13-17.

23. Ali, B.M.M.; Ghoname, N.F.; Hodeib, A.A.; Elbadawy, M.A. Significance of topical propolis in the treatment of facial acne vulgaris. Egypt J. Dermatol. Venerol. 2015, 35, 29-36. [CrossRef]

24. Cheikhyoussef, N.; Cheikhyoussef, A. Vegetable oils as green solvents in the pharmaceutical industry. In Green Sustainable Process for Chemical and Environmental Engineering and Science - Solvents for the Pharmaceutical Industry, 1st ed.; Inamuddin; Boddula, R., Ahamed, M.I., Asiri, A.M., Eds.; Elsevier: Amsterdam, The Netherlands, 2020; pp. 1-11. [CrossRef]

25. Pavel, C.I.; Mărghitaș, L.A.; Bobiș, O.; Dezmirean, D.S.; Șapcaliu, A.; Radoi, I.; Mădaș, M.N. Biological activities of royal jelly-Review. Sci. Pap. Anim. Sci. Biotechnol. 2011, 44, 108-118.

26. El-Wahed, A.A.A.; Khalifa, S.A.M.; Elashal, M.H.; Musharraf, S.G.; Saeed, A.; Khatib, A.; Tahir, H.E.; Zou, X.; Naggar, Y.A.; Mehmood, A.; et al. Cosmetic Applications of Bee Venom. Toxins 2021, 13, 810. [CrossRef] [PubMed]

27. Shah, S.; Gupta, A.; Karne, S.P.; Kamble, S.; Shinde, B. Anti-inflammatory activity of sting protein from Apis mellifera. Int. J. Life Sci. Sci. Res. 2017, 3, 914-919. [CrossRef]

28. Han, S.M.; Kim, J.M.; Hong, I.P.; Woo, S.O.; Kim, S.G.; Jang, H.R.; Pak, S.C. Antibacterial activity and antibiotic-enhancing effects of honeybee venom against methicillin-resistant Staphylococcus aureus. Molecules 2016, 21, 79. [CrossRef] [PubMed]

29. Kopczyńska, D.; Klasik-Ciszewska, S.; Duda-Grychtoł, K. Bee products in skin care. Med. Rodz. 2018, 21, 48-52. [CrossRef]

30. Bruusgaard-Mouritsen, M.A.; Johansen, J.D.; Zachariae, C.; Kirkeby, C.S.; Garvey, L.H. Natural ingredients in cosmetic productsA suggestion for a screening series for skin allergy. Contact Dermat. 2020, 83, 251-270. [CrossRef]

31. Latheef, F.; Wilkinson, M. Adverse skin reactions to cosmetics and skin care products. In Contact Dermatitis, 1st ed.; Johansen, J.D., Mahler, V., Lepoittevin, J.P., Frosch, P.J., Eds.; Springer: New York, NY, USA, 2020; pp. 913-932. [CrossRef]

32. Melnick, S.C. Occurrence of Collagen in the Phylum Mollusca. Nature 1958, 181, 1483. [CrossRef]

33. Williams, A.P. The chemical composition of snail gelatin. Biochem. J. 1960, 74, 304-307. [CrossRef]

34. González, M.A.; Egaña, M.P.; Muñoz, N.; Correa, P.B. Crema de caracol para tratamiento coadyudante de cicatrices de quemaduras e injertos. Rev. Chil. Ter. Ocup. 2004, 4, 5-10. [CrossRef]

35. Smith, A.M.; Morin, M.C. Biochemical differences between trail mucus and adhesive mucus from marsh periwinkle snails. Biol. Bull. 2002, 203, 338-346. [CrossRef]

36. Trapella, C.; Rizzo, R.; Gallo, S.; Alogna, A.; Bortolotti, D.; Casciano, F.; Zauli, G.; Secchiero, P.; Voltan, R. HelixComplex snail mucus exhibits pro-survival, proliferative and pro-migration effects on mammalian fibroblasts. Sci. Rep. 2018, 8, 1-10. [CrossRef] [PubMed]

37. Nail, B.; Elmore, A.R. Cosmetic Ingredient Review Expert panel. Final report on the safety assessment of human placental protein, hydrolyzed human placental protein, human placental enzymes, human placental lipids, human umbilical extract, placental protein, hydrolyzed placental protein, placental enzymes, placental lipids, and umbilical extract. Int. J. Toxicol. 2002, 21 , 81-91. [CrossRef]

38. Nguyen, J.K.; Masub, N.; Jagdeo, J. Bioactive ingredients in Korean cosmeceuticals: Trends and research evidence. J. Cosmet. Dermatol 2020, 19, 1555-1569. [CrossRef]

39. Davison-Kotler, E.; Marshall, W.S.; García-Gareta, E. Sources of collagen for biomaterials in skin wound healing. Bioengineering 2019, 6, 56. [CrossRef]

40. Avila Rodríguez, M.I.; Rodríguez Barroso, L.G.; Sánchez, M.L. Collagen: A review on its sources and potential cosmetic applications. J. Cosmet. Dermatol. 2018, 17, 20-26. [CrossRef] [PubMed]

41. Alparslan, L.; Şekeroğlu, N.; Kijjoa, A. The Potential of Marine Resources in Cosmetics. Curr. Perspect. Med. Aromat. Plants 2018, 1 , 53-66. [CrossRef]

42. Felician, F.F.; Xia, C.; Qi, W.; Xu, H. Collagen from marine biological sources and medical applications. Chem. Biodivers. 2018, 15, e1700557. [CrossRef]

43. Langmaier, F.; Mládek, M.; Kolomazník, K.; Sukop, S. Isolation of elastin and collagen polypeptides from long cattle tendons as raw material for the cosmetic industry. Int. J. Cosmet. Sci. 2002, 24, 273-279. [CrossRef] [PubMed]

44. Chilakamarry, C.R.; Mahmood, S.; Saffe, S.N.B.M.; Arifin, M.A.B.; Gupta, A.; Sikkandar, M.Y.; Begum, S.S.; Narasaiah, B. Extraction and application of keratin from natural resources: A review. 3 Biotech 2021, 11, 1-12. [CrossRef] [PubMed]

45. Abdallah, M.M.; Fernández, N.; Matias, A.A.; do Rosário Bronze, M. Hyaluronic acid and Chondroitin sulfate from marine and terrestrial sources: Extraction and purification methods. Carbohydr. Polym. 2020, 243, 116441. [CrossRef]

46. Essendoubi, M.; Gobinet, C.; Reynaud, R.; Angiboust, J.F.; Manfait, M.; Piot, O. Human skin penetration of hyaluronic acid of different molecular weights as probed by Raman spectroscopy. Skin Res. Technol. 2016, 22, 55-62. [CrossRef] [PubMed]

47. Pavicic, T.; Gauglitz, G.G.; Lersch, P.; Schwach-Abdellaoui, K.; Malle, B.; Korting, H.C.; Farwick, M. Efficacy of cream-based novel formulations of hyaluronic acid of different molecular weights in anti-wrinkle treatment. J. Drugs Dermatol. 2011, 10, 990-1000. [PubMed] 
48. Engels, P.; Kneip, T. The Physiological Importance of Hyaluronic Acids and Effects of Topical Applied Formulations. 2020. Available online: https:/ / www.thomas-kneip.de/files/Wissenschaftsartikel_The $\% 20$ Physiological\%20Importance $\% 20$ of $\% 20$ HA_DrPEngelsTKneip.pdf (accessed on 14 December 2021).

49. Clarke, R. The origin of ambergris. Lat. Am. J. Aquat. Mamm. 2006, 5. [CrossRef]

50. Rice, D.W. Ambergris. In Encyclopedia of Marine Mammals, 2nd ed.; Perrin, W.F., Würsig, B., Thewissen, J.G.M., Eds.; Academic Press: London, UK, 2009; pp. 28-29. [CrossRef]

51. Gilmore, R.M. The whaling industry: Whales, dolphins, and porpoises. In Marine Products of Commerce, 1st ed.; Tressler, D.K., Lemon, J.M., Eds.; Reinhold Publishing Corporation: New York, NY, USA, 1951; pp. 680-715.

52. Ncube, E.N.; Steenkamp, L.; Dubery, I.A. Ambrafuran (AmbroxTM) Synthesis from Natural Plant Product Precursors. Molecules 2020, 25, 3851. [CrossRef] [PubMed]

53. Aranaz, I.; Acosta, N.; Civera, C.; Elorza, B.; Mingo, J.; Castro, C.; Gandía, M.D.1.L.; Heras Caballero, A. Cosmetics and Cosmeceutical Applications of Chitin, Chitosan and Their Derivatives. Polymers 2018, 10, 213. [CrossRef] [PubMed]

54. Hashim, P.; Mat Hashim, D. A review of cosmetic and personal care products: Halal perspective and detection of ingredient. Pertanika J. Sci. Technol. 2013, 21, 281-292. 